\title{
Fine sediment sources in Conservation Effects Assessment Project watersheds
}

\author{
C.G. Wilson, R.A. Kuhnle, S.M. Dabney, R.N. Lerch, C.H. Huang, K.W. King, and S.J. Livingston
}

\begin{abstract}
Two naturally occurring radionuclides, Beryllium-7 $\left({ }^{7} \mathrm{Be}\right)$ and Lead-210 $\left({ }^{210} \mathrm{~Pb}_{\mathrm{xs}}\right)$ were used as tracers to discriminate eroded surface soils from channel-derived sediments in the fine suspended sediment loads of eight Conservation Effects Assessment Project (CEAP) benchmark watersheds. Soil, bank, and suspended sediment samples, as well as rainfall samples, were collected in the watersheds from single storm events and analyzed for the radionuclide activities, which were then applied to a two end-member mixing model to determine the relative proportions from the two source areas. In larger watersheds where the transport length of the sediment was longer, the suspended sediment load contained lower proportions of eroded upland soils compared to smaller systems. The longer transport paths contained more depositional areas in which fine sediment could settle, and hence, less eroded surface soils reached the stream channel, resulting in higher proportions of sediment from the channels. This study showed that more than $50 \%$ of the fine sediment in six of the eight watersheds originated from channel sources that included stream banks, the riverine bed, and gullies. These results underscore the need to consider channel and gully processes when management practices are designed to reduce sediment yield in agricultural watersheds.
\end{abstract}

Agricultural activities have been shown to dramatically increase the runoff of excess rainfall in upland watersheds, which in turn enhances surface soil erosion from the landscape (McGregor et al. 1969; Dendy et al. 1979; Van Oost et al. 2006), as well as the erosion of channel banks (Kuhnle et al. 2008). This enhanced erosion on the landscape and in the stream channel, respectively, reduces the thickness and fertility of the soil and negatively affects fish and other aquatic biota by reducing water clarity, impeding respiration, and eliminating habitat (Newcombe and MacDonald 1991; Shields et al. 1994; Newcombe and Jensen 1996). The eroded sediment, with attached nutrients and other contaminants, from cropped fields also causes eutrophication in downstream waters (Rabalais et al. 1991) and negatively impacts the food chain (Smith et al. 2001).

Annual sediment-related damages in North America have been estimated in the billions (Osterkamp et al. 1998; Duffy 2012); however, abating these damages has been hindered because in many watersheds the main sources of the sediment are not apparent. Even in multiyear watershed stud- suspended sediment load of agricultural streams was shown to be widely applicable in multiple watersheds. The theory behind the method is detailed by Matisoff et al. (2005), Whiting et al. (2005), and Wilson et al. (2008a). The method utilized the activities of two naturally occurring radioisotopes, Beryllium-7 $\left({ }^{7} \mathrm{Be}\right)$ and Lead-210 $\left({ }^{210} \mathrm{~Pb}_{\mathrm{xs}}\right)$, as tracers and a simple two end-member mixing model. Wilson et al. (2008a) showed the applicability of this technique in the varying landscapes of five benchmark watersheds of the Conservation Effects Assessment Project (CEAP) (Duriancik et al. 2008) in Georgia, Iowa, Mississippi, and Oklahoma. Further studies were conducted in additional CEAP watersheds in Indiana, Missouri, Mississippi, and Ohio, whose results are presented herein. Each of the watersheds presented herein and in Wilson et al. (2008a) have different drainage areas, and it was hypothesized that the size of the watershed, which was essentially determined by the choice of the outlet sampling location, would affect the relative partitioning of upland and channel source sediments to the system's streams. In larger watersheds, where the transport pathways of the sediment are longer, a lower proportion of eroded upland soils would be present in the suspended load relative to the proportion of eroded soils in smaller systems (Roehl 1962). The longer transport pathways would contain more depositional areas for in which fine sediment ( $<63 \mu \mathrm{m}$ [0.002 in] ) could settle, and less eroded surface soils would reach the stream channel resulting in higher proportions of channel-derived sediment (Abaci and Papanicolaou 2009).

sources can be identified wher sufficient number of biogeochemical and geophysical properties of the source soils and eroded sediment were measured (Peart and Walling 1986; Walling and Woodward 1992; Rhoton et al. 2008). In many cases, however, the useful suite of properties for differentiating sediments were site specific and not transferable to other areas, as well as too numerous and generally very laborious to collect. Although computer modeling has the potential to identify major sediment sources in watersheds with sediment problems, these models still need more sets of measured data to evaluate and verify their results (Bingner et al. 2006).

In a previous companion study (Wilson et al. 2008a), a simplified sourcing method that coarsely differentiated eroded surface soils and channel-derived sediment to the
Christopher G. Wilson is a research professor in the Civil and Environmental Engineering department at the University of Tennessee in Knoxville, Tennessee. Roger A. Kuhnle is a research hydraulic engineer with the USDA ARS (Agricultural Research Service) National Sedimentation Laboratory in Oxford, Mississippi. Seth M. Dabney is a research leader with the USDA ARS National Sedimentation Laboratory in Oxford, Mississippi. Robert N. Lerch is a soil scientist with the USDA ARS in Columbia, Missouri. Chi Hua Huang is a research leader with the USDA ARS National Soil Erosion Research Laboratory in West Lafayette, Indiana. Kevin W. King is an agricultural engineer with the USDA ARS Soil Drainage Research Unit in Columbus, Ohio. Stanley J. Livingston is a soil scientist with the USDA ARS National Soil Erosion Research Laboratory in West Lafayette, Indiana. 
Study Sites. The eight CEAP benchmark source study sites were located in Georgia, Indiana, Iowa, Mississippi, Missouri, Ohio, and Oklahoma (figure 1). These agricultural watersheds ranged in drainage area from 21 to $6,417 \mathrm{~km}^{2}$ (8 to $2,478 \mathrm{mi}^{2}$ ) with annual precipitation ranging from 750 to $1,500 \mathrm{~mm}$ (29.5 to 59.1 in) (table 1$)$. The percentage of row crops in the watersheds ranged from $4.3 \%$ to $88 \%$ with several watersheds experiencing changes in the row crop percentage during the study period. Three of the watersheds (i.e., Cedar Creek, Indiana; South Fork of the Iowa River, Iowa; and Upper Big Walnut Creek, Ohio) have tile drains which intercept much of the flow of surface water on these watersheds.

All of these watersheds have been identified as sites where water quality problems related to agricultural activities existed and conservation practices had been implemented to improve the water quality leaving the watersheds. Multiyear studies are in progress at each site to quantify the effects of the conservation practices on water quality. The ongoing studies at each of these watersheds greatly facilitated the collection of the samples necessary to conduct a sediment source study at the watersheds.

Descriptions of the sites from Georgia, Iowa, Mississippi, and Oklahoma were detailed in Wilson et al. (2008a). In this paper, characteristics of the sites from Indiana, Missouri, and Ohio are detailed below.

The Cedar Creek Watershed drains 710 $\mathrm{km}^{2}\left(274 \mathrm{mi}^{2}\right)$ in the area just northeast of Ft. Wayne, Indiana, with the majority of the watershed within DeKalb County. For this study, a smaller subwatershed of $43 \mathrm{~km}^{2}$ (17 $\mathrm{mi}^{2}$ ) was sampled. Land use in the watershed is primarily agricultural, with approximately $78 \%$ cropland; $14 \%$ pasture or forage; $6 \%$ woodlands or wetlands; and $2 \%$ urban, industrial, farmsteads and other land uses. The main crops are corn (Zea mays L.) and soybeans (Glycine max L.) with about $10 \%$ in wheat (Triticum aestivum L.). The topography of the watershed varies from rolling hills to nearly level plains and closed depressions. Soils on the watershed were formed from compacted glacial till and have predominant textures of silt loam, silty clay loam, and clay loam. Soil problems consist of oversaturation and erosion. Annual rainfall is $993 \mathrm{~mm}$ (39 in) with an annual runoff of $90 \mathrm{~mm}$ (3.5 in). Water quality problems in the watershed consist of excess sediment, nutrients, and pesticides.

\section{Figure 1}

Locations of the eight Conservation Effects Assessment Project benchmark watersheds used in this study.

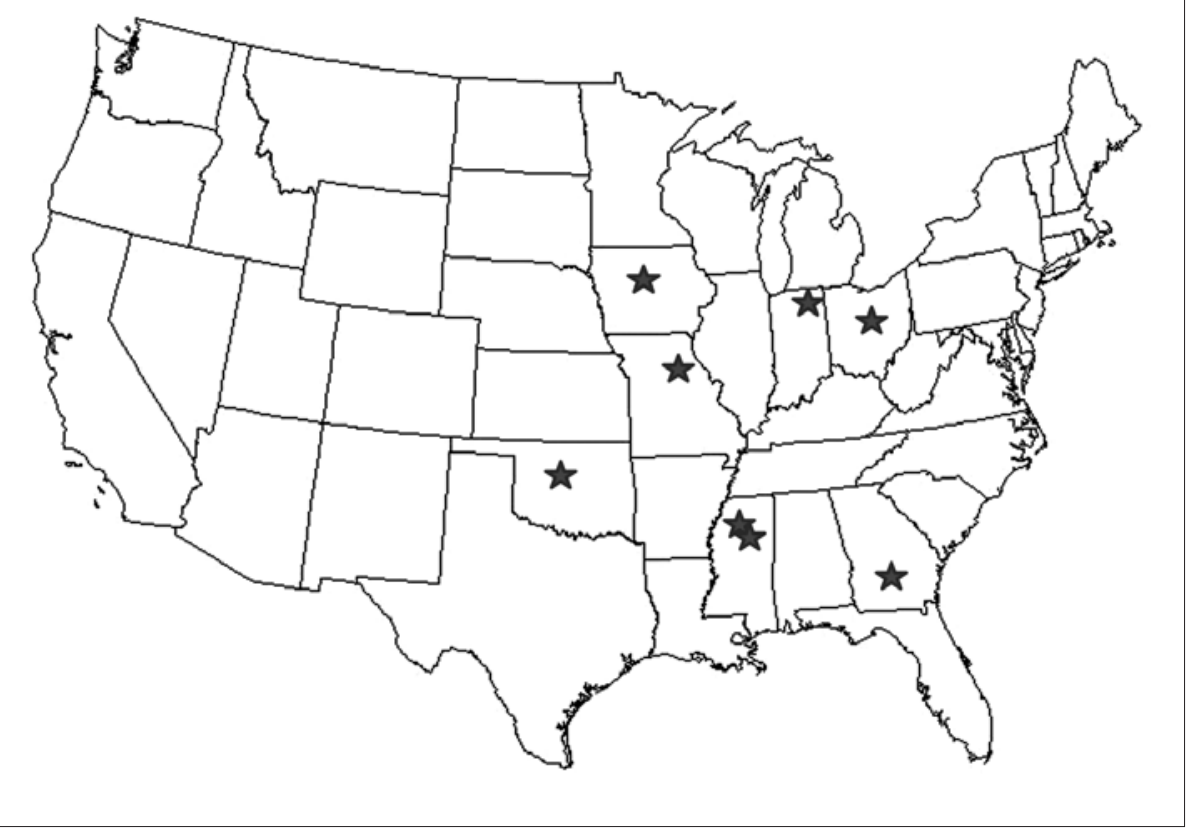

The Goodwater Creek Watershed drains $72 \mathrm{~km}^{2}\left(28 \mathrm{mi}^{2}\right)$ of the Salt River Basin in northeastern Missouri and is a source of water to Mark Twain Lake, a $75 \mathrm{~km}^{2}$ (29 $\mathrm{mi}^{2}$ ) reservoir that is the major public water supply for the region. Soils in the basin were formed in Wisconsinan and Illinoisan loess overlying pre-Illinoisan glacial till. Illuviation of the high clay content loess resulted in the formation of argillic horizons containing $40 \%$ to $60 \%$ smectitic clays. The naturally formed claypan is the key hydrologic feature of the basin and is the direct cause of the high runoff potential of these soils. Topography within the watershed is flat to gently rolling, with most areas having $0 \%$ to 3\% slopes but with long slope lengths. Land use in the Goodwater Creek Watershed consists of $62 \%$ row crop land, primarily soybeans, corn, and sorghum (sorghum bicolor L.); 23\% pasture and other grasslands; $7 \%$ woodland; and $8 \%$ in open water, urban, and wetlands. Average annual precipitation is about $1,000 \mathrm{~mm}$ (39 in) per year, and stream flow accounts for about $30 \%$ of the precipitation. Runoff is about $85 \%$ of the total stream flow. Water quality problems in the watershed consist of runoff contaminated with sediments, nutrients, pesticides, and water-borne pathogens.

The Upper Big Walnut Creek Watershed drains $492 \mathrm{~km}^{2}\left(190 \mathrm{mi}^{2}\right)$ and is located predominantly in Delaware and Morrow counties just north of Columbus, Ohio. The
752 perennial and intermittent stream kilometers (467 miles) of the watershed drain into Hoover Reservoir, which is a water source for about 800,000 residents. For this study, a smaller subwatershed of $4 \mathrm{~km}^{2}$ (1.5 $\mathrm{mi}^{2}$ ) with $71 \%$ in row crops, $24 \%$ in rural residential areas, and 5\% in woodlands was sampled. The average annual precipitation on the watershed is $1,020 \mathrm{~mm}$ (40 in). Crop production agriculture is the largest land use on the watershed, with primary crops of corn, soybeans, and wheat. Soils are generally described as nearly level, clayey, and poorly drained. A large portion of the watershed used for agricultural production is tile-drained, without which agricultural production would be limited. A significant transition from agriculture to urban land use, which may significantly alter the hydrology and water quality characteristics on the watershed, is occurring. Water quality problems consist of too high concentrations of atrazine as well as other agrochemicals. There exists a considerable potential for soil erosion in the watershed.

\section{Materials and Methods}

Soil/sediment samples were collected in each of the eight watersheds from the landscape surface in upland agricultural areas and from vertical cores along the stream Georgia, where cores from the stream bed banks. One exception was the Little River, 
Table 1

The eight Conservation Effects Assessment Project benchmark watersheds considered in this study.

\begin{tabular}{|c|c|c|c|c|c|c|c|c|}
\hline Watershed & Location & $\begin{array}{l}\text { Area } \\
\left(\mathbf{k m}^{2}\right) \\
\end{array}$ & $\begin{array}{l}\text { Annual } \\
\text { precipitation } \\
(\mathrm{mm})\end{array}$ & $\begin{array}{l}\text { Row crops } \\
\text { in source } \\
\text { sampled } \\
\text { watershed (\%) }\end{array}$ & $\begin{array}{l}\text { Tile } \\
\text { drained }\end{array}$ & $\begin{array}{l}\text { Water } \\
\text { quality } \\
\text { problems }\end{array}$ & Soils & Other \\
\hline $\begin{array}{l}\text { Topashaw Canal, } \\
\text { Mississippi } \\
\text { (samples collected } \\
\text { Little Topashaw } \\
\text { Creek) }\end{array}$ & $\begin{array}{l}\text { Rel flat } \\
\text { alluvial } \\
\text { plains along } \\
\text { streams, } \\
\text { steep forested } \\
\text { hillslopes }\end{array}$ & $\begin{array}{l}110 \\
\text { (Little } \\
\text { Topashaw } \\
\text { Creek 37) }\end{array}$ & $\begin{array}{l}1,500 \\
\text { (highest avg } \\
\text { Nov. to Feb., } \\
\text { lowest July } \\
\text { to Sept. }\end{array}$ & $\begin{array}{l}6.5 \\
\text { (Little } \\
\text { Topashaw } \\
\text { Creek) }\end{array}$ & No & $\begin{array}{l}\text { Soil loss, sediment, } \\
\text { gully erosion, } \\
\text { streambank failure }\end{array}$ & $\begin{array}{l}\text { Dispersive silt } \\
\text { and clay soils } \\
\text { overlie sand } \\
\text { which overlies } \\
\text { consolidated } \\
\text { clays }\end{array}$ & $\begin{array}{l}\text { Consolidated } \\
\text { clays form much } \\
\text { of stream } \\
\text { bottoms }\end{array}$ \\
\hline $\begin{array}{l}\text { Cedar Creek, } \\
\text { Indiana (samples } \\
\text { collected } 43 \mathrm{~km}^{2} \\
\text { subbasin) }\end{array}$ & $\begin{array}{l}\text { Pothole or } \\
\text { closed } \\
\text { depressions } \\
\text { of Indiana }\end{array}$ & $\begin{array}{l}710 \\
\text { (43 for } \\
\text { sampled } \\
\text { area) }\end{array}$ & $\begin{array}{l}907 \\
\text { (64-year } \\
\text { record) }\end{array}$ & $\begin{array}{l}78 \text { (43 for } \\
\text { sampled area), }\end{array}$ & $\begin{array}{l}\text { yes } \\
\text { ( } 56 \% \\
\text { of area) }\end{array}$ & $\begin{array}{l}\mathrm{N} \text { and } \mathrm{P} \\
\text { loading from tile } \\
\text { drains }\end{array}$ & $\begin{array}{l}\text { Mollisols } \\
\text { (grasslands) } \\
\text { alfisols } \\
\text { (forested lands) } \\
\text { derived from } \\
\text { glacial till }\end{array}$ & $\begin{array}{l}\text { Hydrographs have } \\
\text { two peaks, one } \\
\text { direct runoff, two } \\
\text { from tile drains }\end{array}$ \\
\hline $\begin{array}{l}\text { South fork of the } \\
\text { lowa River, lowa } \\
\text { (samples collected } \\
\text { Tipton Creek) }\end{array}$ & $\begin{array}{l}\text { lowa central } \\
\text { lowlands } \\
\text { province, } \\
\text { glacial till } \\
\text { comprises } \\
\text { most of } \\
\text { young } \\
\text { landscape } \\
(10,000 \mathrm{y})\end{array}$ & $\begin{array}{l}780 \text { (Tipton } \\
\text { Creek 198) }\end{array}$ & $\begin{array}{l}750 \text { ( } 60 \% \\
\text { May to Aug.) }\end{array}$ & $\begin{array}{l}88 \\
\text { (Tipton Creek) }\end{array}$ & $\begin{array}{l}\text { Yes, } \\
\text { (80\% } \\
\text { of area) }\end{array}$ & $\begin{array}{l}\text { High N, P, and } \\
\text { sediment }\end{array}$ & $\begin{array}{l}54 \% \text { hydric } \\
\text { soils, wetness } \\
\text { a major } \\
\text { concern }\end{array}$ & $\begin{array}{l}\text { Baseflow is } 65 \% \\
\text { of total mostly } \\
\text { from tile drains, } \\
\text { terrain poorly } \\
\text { dissected, poorly } \\
\text { drained }\end{array}$ \\
\hline $\begin{array}{l}\text { Mark Twain Lake, } \\
\text { Salt River Basin, } \\
\text { Missouri (samples } \\
\text { collected } 72 \text { km² }^{2} \\
\text { subbasin) }\end{array}$ & $\begin{array}{l}\text { Dissected } \\
\text { till plains } \\
\text { physiographic } \\
\text { region, flat to } \\
\text { gently rolling } \\
\text { topography } \\
\text { to deeply } \\
\text { dissected nr } \\
\text { major } \\
\text { tributaries }\end{array}$ & $\begin{array}{l}6,417(72- \\
\text { subbasin of } \\
\text { Goodwater } \\
\text { Creek) }\end{array}$ & 809 to 909 & $\begin{array}{l}63 \\
\text { (subbasin of } \\
\text { Goodwater } \\
\text { Creek) }\end{array}$ & No & $\begin{array}{l}\text { Problem with } \\
\text { herbicides and } \\
\text { sediment, clay-pan } \\
\text { promotes surface } \\
\text { runoff and transport } \\
\text { of herbicides and } \\
\text { sediment. } \\
\mathrm{N} \text { contamination of } \\
\text { of groundwater }\end{array}$ & $\begin{array}{l}\text { Clay-pan soils } \\
\text { predominant } \\
\text { (subsoil } \\
\text { horizon with } \\
\text { abrupt and } \\
\text { large increase } \\
\text { in clay content } \\
\text { (smectite) }\end{array}$ & $\begin{array}{l}\text { During winter and } \\
\text { spring subsurface } \\
\text { clays swollen, } \\
\text { impedes } \\
\text { infiltration, and } \\
\text { perched water } \\
\text { above clay pan } \\
\text { causes high } \\
\text { probability of } \\
\text { runoff }\end{array}$ \\
\hline
\end{tabular}




\section{Table 2}

\begin{tabular}{|c|c|c|c|c|c|c|}
\hline Watershed & Date & $\begin{array}{l}\text { Event } \\
\text { rainfall } \\
(\mathrm{mm})\end{array}$ & $\begin{array}{l}\text { Event } \\
\text { duration (h) }\end{array}$ & $\begin{array}{l}\text { Rainfall in } \\
\text { week prior } \\
\text { to sampled } \\
\text { event }(\mathrm{mm})\end{array}$ & 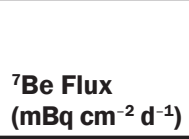 & $\begin{array}{l}{ }^{210} \mathrm{~Pb}_{\mathrm{xs}} \text { Flux } \\
\left(\mathrm{mBq} \mathrm{cm} \mathrm{cm}^{-2} \mathrm{~d}^{-1}\right)\end{array}$ \\
\hline Goodwin Creek, Mississippi† & January 7, 2005 & 27.68 & 17.0 & 16.76 & 4.79 & 0.259 \\
\hline Goodwin Creek, Mississippi & December 28, 2007 & 28.96 & 7.6 & 25.40 & 1.82 & 0.149 \\
\hline Cedar Creek, Indiana & July 19, 2007 & 54.61 & 16.7 & 5.59 & 0.293 & 0.025 \\
\hline Goodwater Creek, Missouri & March 29, 2007 & 32.26 & 30.0 & 11.18 & 11.4 & 0.411 \\
\hline
\end{tabular}

were collected instead from the banks. The Little River is a low-gradient depositional environment, where the steam banks were small (less than $1 \mathrm{~m}[3.3 \mathrm{ft}]$ ), relatively restabilized, and contained nearly $100 \%$ vegetation (Simon and Klimetz 2008). These soil/sediment samples were used to define representative background activities of ${ }^{7} \mathrm{Be}$ and ${ }^{210} \mathrm{~Pb}_{\mathrm{xs}}$ of the source areas (i.e., upland and stream banks).

The ${ }^{7} \mathrm{Be}$ and ${ }^{210} \mathrm{~Pb}_{\mathrm{xs}}$ present in the atmosphere are delivered to the landscape mainly during precipitation events where they quickly and strongly bond to surface silt and clay particles (He and Walling 1996) through cation exchange. The deposited ${ }^{7} \mathrm{Be}$ develops an exponential profile in the top few centimeters of the soil column, while the ${ }^{210} \mathrm{~Pb}$, extends slightly deeper due to a longer half-life (Wallbrink and Murray 1996; Bonniwell et al. 1999).

The assumption was made that erosion from the land surface generally occurs in thin layers from the soil surface in fields that have been recently disturbed from tillage, planting, harvest, or other agricultural activity. Thus, all of the upland samples were collected in agricultural fields. Typically five to nine fields were sampled within each watershed with one sample per field. A three-sided box corer with a sampling area of $233 \mathrm{~cm}^{2}\left(36.1 \mathrm{in}^{2}\right)$ was driven into the side of a pit excavated in the field (Wilson et al. 2003) and used to collect $0.5 \mathrm{~cm}(0.20 \mathrm{in})$ slices to a depth of $2 \mathrm{~cm}$ (0.78 in). The top $2 \mathrm{~cm}$ (0.78 in) of the sample were used to define a radionuclide profile as previous work had established that ${ }^{7} \mathrm{Be}$ had a very limited depth of penetration (Wallbrink and Murray 1996; Bonniwell et al. 1999; Matisoff et al. 2002a; 2002b).

Sampling of the other sediment source, namely the stream banks, required cores to a greater depth because bank failures tend to remove larger volumes of sediment from significantly below the ground surface. Stream bank sediments receive little atmospheric radionuclide input due to near-vertical slopes (Whiting et al. 2005), and mass failure can remove large volumes of material (Brigham et al. 2001) so that the high-activity bank soil at the surface is diluted with a much larger volume of low-activity sediment from deeper in the collapsed bank Cores with a $2.5 \mathrm{~cm}$ (1 in) diameter were collected using a hammer-driven corer in 33 $\mathrm{cm}$ (13 in) intervals to a depth of $99 \mathrm{~cm}$ (39 in). Three to five bank cores were collected for each watershed.

The upland soils and bank sediment samples were dried at $60^{\circ} \mathrm{C}\left(104^{\circ} \mathrm{F}\right)$, weighed, and separated into sand, silt, and clay sized particles using $\left(\mathrm{NaPO}_{3}\right)_{6}$ dispersant. After each mixture was placed on a shaker overnight, the sand particles were separated using a $63 \mu \mathrm{m}(0.002 \mathrm{in})$ sieve. The remaining mixture of sediment and fluid was placed on an automated, large-volume, particle size separator (Rutledge et al. 1967) to separate the silt and the clay $\left(2 \mu \mathrm{m}\left[7.9 \times 10^{-5} \mathrm{in}\right]\right)$ fractions (Wilson et al. 2008a).

Water and suspended sediment samples were also collected, which occurred during individual runoff events following the source sampling. Every effort was made to sample the first runoff event following the source sampling as to maintain a strong correlation between the sources and the collected suspended sediment in the stream. This time ranged from 2 days to 73 days for the events referred to in this study (table 2).

Discrete suspended sediment and water samples of the wash load were collected near subwatershed outlets throughout the runoff event hydrographs using plastic buck- ets with a volume of $19 \mathrm{~L}$ (5 gal) from the center of the channel near the water surface. After settling and dewatering each sample individually, the sediment was dried at $60^{\circ} \mathrm{C}$ $\left(104^{\circ} \mathrm{F}\right)$, weighed, and separated into sand, silt, and clay-sized particles.

Samples of precipitation were also collected during these runoff events at four to six locations within the subwatersheds to measure atmospheric delivery of the radionuclides. Nineteen-liter ( 5 gal) buckets were mounted on top of stands that were $1 \mathrm{~m}(3.28 \mathrm{ft})$ above the ground. The radionuclides in the precipitation samples were collected by precipitating them on a $\mathrm{Fe}(\mathrm{OH})_{3}$ (ferric acid) floc.

The activities of the ${ }^{7} \mathrm{Be}$ and ${ }^{210} \mathrm{~Pb}_{\mathrm{xs}}$ in the soil, bank, and suspended sediment samples, as well as the precipitated rainfall samples were determined using gamma spectroscopy. Standard geometries were used with all samples as they were counted for at least 82,800 seconds on a High Purity Germanium gamma detector and then for an additional 300 seconds with a standardized sealed source to account for self-absorption of the ${ }^{210} \mathrm{~Pb}$ photon (Cutshall et al. 1983). Counting efficiencies were established using a standard radionuclide solution (Bonniwell 2001; Wilson et al. 2003).

\section{Results and Discussion}

Herein, the results will mainly focus on four of the eight watersheds, namely Cedar Creek, Indiana; Goodwater Creek, Missouri; Goodwin Creek, Missouri; and Upper Big Walnut Creek, Ohio. The results for the remaining watersheds were presented in the companion paper by Wilson et al. (2008a). However, some of these previously presented results will be used to provide a summary discussion on all the watersheds later in this section. 
Atmospheric Influxes of ${ }^{7} \mathrm{Be}$ and ${ }^{210} \mathrm{~Pb}$. In Goodwater Creek and subwatersheds in Cedar and Upper Big Walnut Creeks, one runoff event was sampled, while in Goodwin Creek four runoff events were sampled (table 2 ). The average atmospheric influxes of ${ }^{7} \mathrm{Be}$ and ${ }^{210} \mathrm{~Pb}_{\mathrm{xs}}$ collected during these individual events at each site varied considerably ranging from 0.165 to $11.4 \mathrm{mBq} \mathrm{cm}^{-2} \mathrm{~d}^{-1}$ (0.064 to $\left.4.41 \mathrm{dpm} \mathrm{in}^{-2} \mathrm{~d}^{-1}\right)$ for ${ }^{7} \mathrm{Be}$ and from 0.001 to $0.411 \mathrm{mBq} \mathrm{cm}^{-2} \mathrm{~d}^{-1}$ (0.0004 to $0.159 \mathrm{dpm} /$ $\mathrm{in}^{-2} \mathrm{~d}^{-1}$ ) for ${ }^{210} \mathrm{~Pb}_{\mathrm{xs}}$ (figure 2). As these sites were from a relatively similar geographic location (i.e., the midcontinental United States), the variations in fluxes between these sites were due to differences in the specific event characteristics (table 2), such as duration, intensity, and timing (Baskaran et al. 1993; Matisoff et al. 2005). For example, the two events with the highest atmospheric influxes of ${ }^{7} \mathrm{Be}$ and ${ }^{210} \mathrm{~Pb}_{\mathrm{xs}}$ occurred during the spring (March and April). Maximum depositional fluxes in spring were observed in other studies and are thought to represent seasonal precipitation washout by thunderstorms (Dibb and Rice 1989; Robbins and Eadie 1991; Bonniwell 2001; Wilson et al. 2005).

Temporal variations of atmospheric influxes at the Goodwin Creek site for the two radionuclides were further examined (table 2) and consistent with long-term measurements from other sites (Todd et al. 1989; Wilson et al. 2005). At Goodwin Creek, the atmospheric influxes of ${ }^{7} \mathrm{Be}$ and ${ }^{210} \mathrm{~Pb}$, were highest during the sampled spring thunderstorm in April of 2004. This event was by far the most intense event of the four with $20.6 \mathrm{~mm}(0.81 \mathrm{in})$ in approximately 2 hours. Intense thunderstorms can reach high into the stratosphere mining high pools of ${ }^{7} \mathrm{Be}$ (Arnold and Al-Salih 1955).

Moreover, long events or events that are preceded by multiple, other storms may experience washout of the radionuclides before the end of the event (Turekian et al. 1983). The durations of the other three events in Goodwin Creek lasted longer than 8 hours. In addition, the atmospheric influxes of the radionuclides appeared to be inversely related to the amount of rain in the week prior to the sampled event. The sampled events with higher amounts of antecedent rainfall in the week prior to sampling had lower measured atmospheric influxes (table 2) showing the washout of the atmosphere prior to the measured event.

\section{Figure 2}

Atmospheric influxes of ${ }^{7} \mathrm{Be}$ and ${ }^{210} \mathrm{~Pb}_{\mathrm{xs}}$ to different watersheds in the United States. Sites from this study include, Cedar Creek, Indiana; Goodwater Creek, Missouri; Goodwin Creek, Mississippi; and Upper Big Walnut Creek, Ohio, watersheds. Sites from Wilson et al. (2008) were in Georgia, lowa, Mississippi, and Oklahoma. Sites from Wilson (2003) include additional watersheds in Alabama, Ohio, and Oregon.

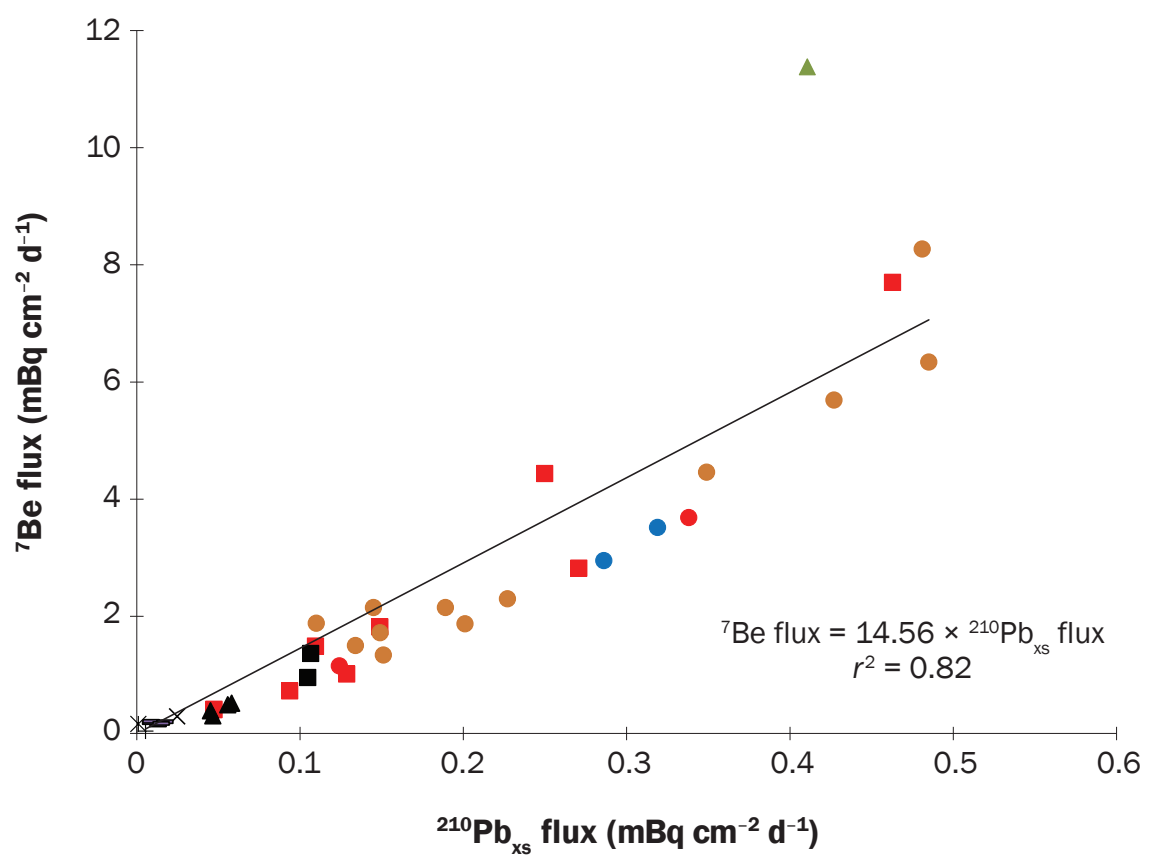

\section{Legend}

$\times$ Cedar Creek

$\Delta$ Goodwater Creek

- Goodwin Creek

* Upper Big Walnut Creek

+ Fort Cobb

- Little Rive

\author{
South Fork of lowa River \\ - Toposhaw Creek \\ - Old Woman Creek \\ - South Slough \\ - Weeks Bay
}

Despite the variable atmospheric influxes of ${ }^{7} \mathrm{Be}$ and ${ }^{210} \mathrm{~Pb}$ across these sites, a plot of the radionuclide fluxes relative to one another, along with data from other sites around the United States (Wilson 2003; Wilson et al. 2008a), showed a very strong linear relationship $\left(r^{2}=0.82\right.$; figure 2$)$. The slope of the linear trend line, which was approximately 14.5 , was similar to other studies (Baskaran et al. 1993; Matisoff et al. 2005) that observed values around 16.

The strong correlation between the ${ }^{7} \mathrm{Be}$ and ${ }^{210} \mathrm{~Pb}_{\mathrm{xs}}$ in the atmospheric influxes suggests that the delivery mechanism of the two radionuclides to the landscape surface is similar. The similar delivery mechanism and the high partition coefficients of the two radionuclides $\left(\mathrm{K}_{\mathrm{d}} \sim 10^{4}\right.$ to $\left.10^{6}\right)$ (Hawley et al. 1986; Wilson 2003) that reflect their preferential and rapid bonding to soil particles support the paired use of the two radionu- clides as tracers in studies of individual runoff events (Matisoff et al. 2005).

Source Sediments. To determine the activity of the eroded surface soils at each site, which is herein used as the signature of the upland source material, the atmospheric influxes of ${ }^{7} \mathrm{Be}$ and ${ }^{210} \mathrm{~Pb}_{\mathrm{xs}}$ were distributed over the activity profiles of the collected soil samples with an exponential function (Wilson et al. 2003). Many previous studies (Owens et al. 1996; Wallbrink and Murray 1996; Bonniwell et al. 1999) have observed exponential profiles of these radionuclides to a limited depth (i.e., a few centimeters) in the soil column. These profiles were attributed to the rapid bonding of the atmospherically delivered radionuclides to the fine particles at the soil surface and their rapid decay (Bierman et al. 1998).

Additionally, the activities of each sample were further adjusted using average enrich- 
ment coefficients for the two radionuclides determined at each site to account for preferential erosion of the finer particles during erosion (Rhoton et al. 1979). Enrichment coefficients herein were defined as the ratio of the activity of the clay particles relative to the activity of the bulk sediment for the surface soil samples. They were determined by initially quantifying the activities of the bulk samples, then performing a repeated analysis on just the clay portion of the sample, which was separated through settling. The magnitudes of the enrichment coefficients averaged $6.2 \pm 1.9$ for ${ }^{7} \mathrm{Be}$ and $4 \pm 1.6$ for ${ }^{210} \mathrm{~Pb}_{\mathrm{xs}}$, which is explained by the selective nature of the radionuclide to bind only to finer-sized soil particles. These values are in the range of other studies ( $\mathrm{He}$ and Walling 1996), and the relatively high values emphasize the importance of separating the clay fraction in radionuclide studies.

From each watershed, the activities of ${ }^{7} \mathrm{Be}$ and ${ }^{210} \mathrm{~Pb}$ in the collected soils were pooled to develop a composite profile of the upland source material for that watershed. The logs of these activities were plotted against their depth in the soil column and fit with a linear function (figure 3 ). From the linear fit through the data of these pooled profiles, the activities at depth equal to $0 \mathrm{~cm}(0$ in) was assumed to be the surface activity, or the signature of the upland source material (Wilson et al. 2003). Pooling the activity profiles was considered due to the observed spatial variability at each site (Wilson et al. 2003), as the coefficient of variation of the top samples before each of the five events in this study averaged $44 \% \pm 9 \%$ for ${ }^{7} \mathrm{Be}$ and $22 \% \pm 4 \%$ for ${ }^{210} \mathrm{~Pb}_{\mathrm{xx}}$.

Surface soil activities of ${ }^{7} \mathrm{Be}$ (ranging from 282 to $1,680 \mathrm{mBq} \mathrm{g}^{-1}$ [479 to $2,856 \mathrm{dpm}$ $\left.\mathrm{Oz}^{-1}\right]$ ) were high relative to corresponding activities of ${ }^{210} \mathrm{~Pb}_{\mathrm{xs}}$ (ranging from 102 to $378 \mathrm{mBq} \mathrm{g}^{-1}$ [173 to $\left.643 \mathrm{dpm} \mathrm{oz}^{-1}\right]$ ), which resulted from the relationship between the radionuclides in the atmospheric influxes. However, the ${ }^{7} \mathrm{Be}$ to ${ }^{210} \mathrm{~Pb}_{\mathrm{xs}}$ ratio in the soils averaged 6.7; in the atmospheric influx, the ratio was greater than 14 . The lower radionuclide activities in the soil surface resulted from dilution of the high radionuclide activities in the atmospheric influxes with decaying radionuclide stores from previous events that were already in the soil (Matisoff et al. 2005).

Conversely, the measured activities of ${ }^{210} \mathrm{~Pb}_{\mathrm{xs}}$ and ${ }^{7} \mathrm{Be}$ from $1 \mathrm{~m}(3.3 \mathrm{ft})$ cores col-

\section{Figure 3}

Composite profiles of ${ }^{7} \mathrm{Be}$ and ${ }^{210} \mathrm{~Pb}_{\mathrm{xs}}$ in surface soils from Goodwater Creek, Missouri. The atmospheric influxes of the radionuclides and enrichment ratios were added, as described herein.

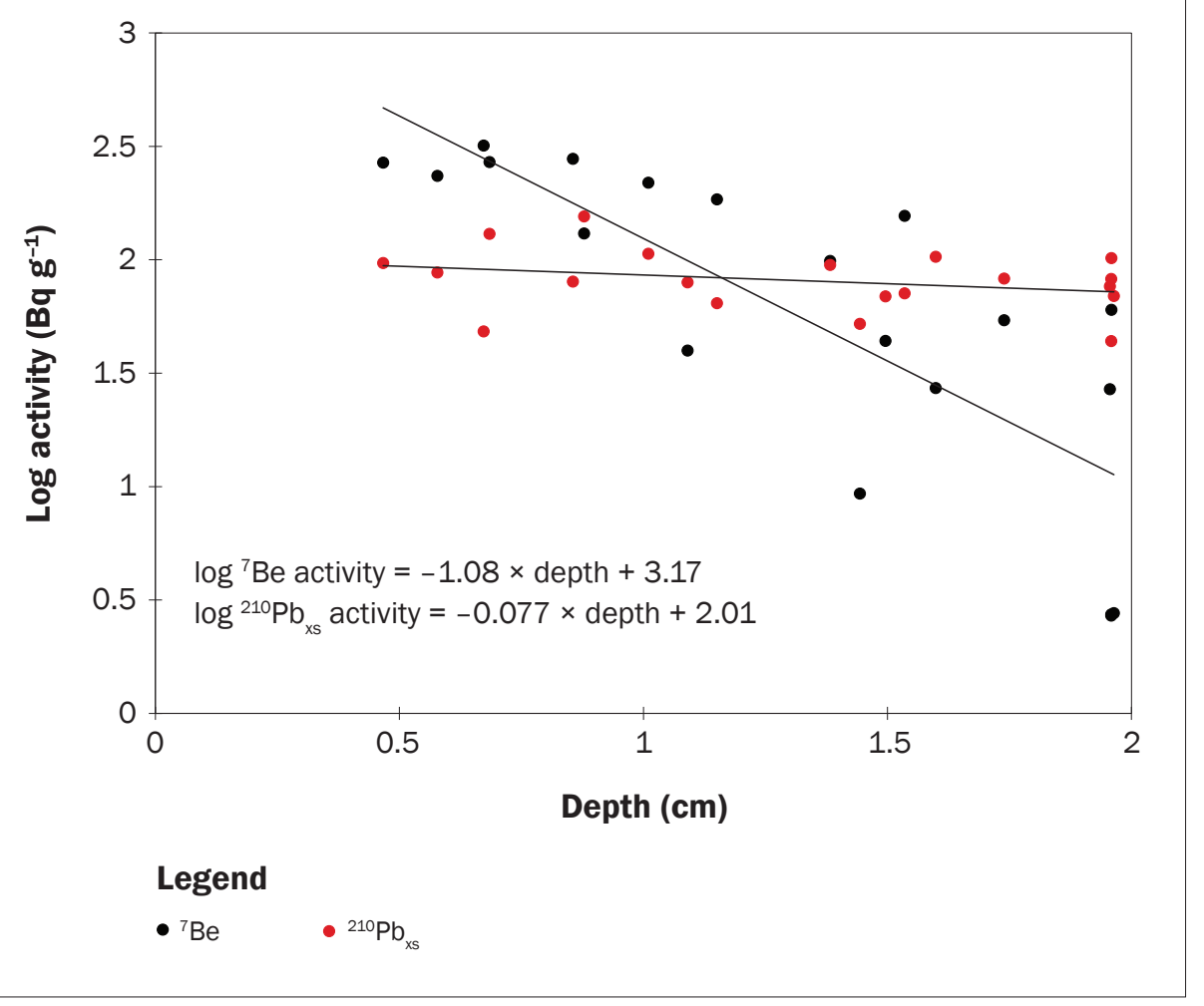

lected along actively eroding bank faces were low relative to the eroded surface soils by at least an order of magnitude. The integration of the activities over the length of the bank face incorporated a vast majority of soil particles deficient in ${ }^{7} \mathrm{Be}$ and ${ }^{210} \mathrm{~Pb}_{\mathrm{xs}}$, as the two radionuclides are found only within the top few centimeters of the soil column (Wallbrink and Murray 1996; He and Walling 1997; Bonniwell et al. 1999; Wilson et al. 2003). Bank heights at these sites were often greater than $1 \mathrm{~m}(3.3 \mathrm{ft})$.

The average activities of ${ }^{7} \mathrm{Be}$ and ${ }^{210} \mathrm{~Pb}_{\mathrm{xs}}$ of the source sediments (i.e., eroded surface soils and channel bank sediment) were plotted against one another (figure 4). The source sediments plotted at different ends of the graphs suggesting that the two activities used in conjunction do provide a unique signature for each source material despite the potentially high spatial variability of activities across a landscape. Despite the variation found in the soil surface samples within a watershed (the coefficient of variation averaged $44 \% \pm 9 \%$ for ${ }^{7} \mathrm{Be}$ and $22 \% \pm 4 \%$ for ${ }^{210} \mathrm{~Pb}_{\mathrm{xs}}$ for the different watersheds), there was still a significant difference between the upland and channel sources (figure 4). Similar results were seen from the watersheds used in Wilson et al. (2008a).

Suspended Sediment. The activities of ${ }^{7} \mathrm{Be}$ and ${ }^{210} \mathrm{~Pb}$ for the fine suspended sediment collected during the runoff events in each watershed were plotted along a mixing line between their two respective source sediments. The activity value for each suspended sediment activity was projected perpendicularly towards the mixing line to determine the relative percentage of each source material contained in that sample. Visually examining the position of the suspended sediment samples relative to the two sources in figure 4 revealed that, for the most part, the suspended sediment samples covered the entire spectrum from being comprised entirely of eroded surface soils to being dominated by channel bank sediments. Suspended sediment samples collected at Goodwater Creek plotted closer to the bank sediment signature (figure $4 \mathrm{a}$ ), while suspended sediment samples collected in the Upper Big Walnut Creek subwatershed plotted closer to the eroded surface soil signature (figure $4 \mathrm{c}$ ). The samples from the Cedar Creek subwatershed plotted over the whole range between the two source sediments (figure $4 b$ ). 


\section{Figure 4}

End member models for (a) Goodwater Creek, (b) Cedar Creek, and (c) Upper Big Walnut Creek.

(a)

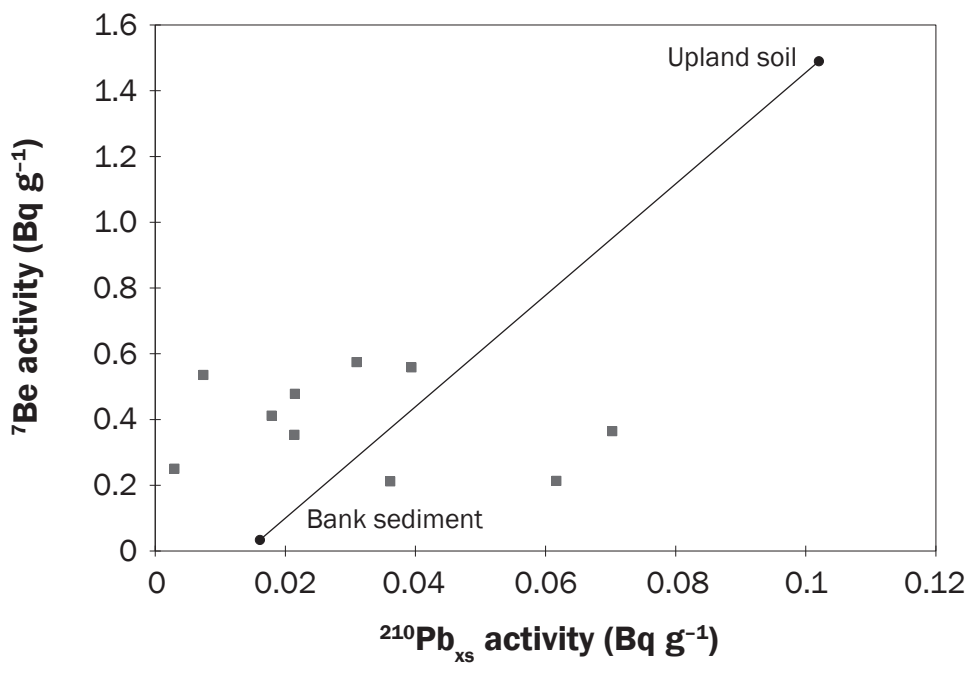

(b)

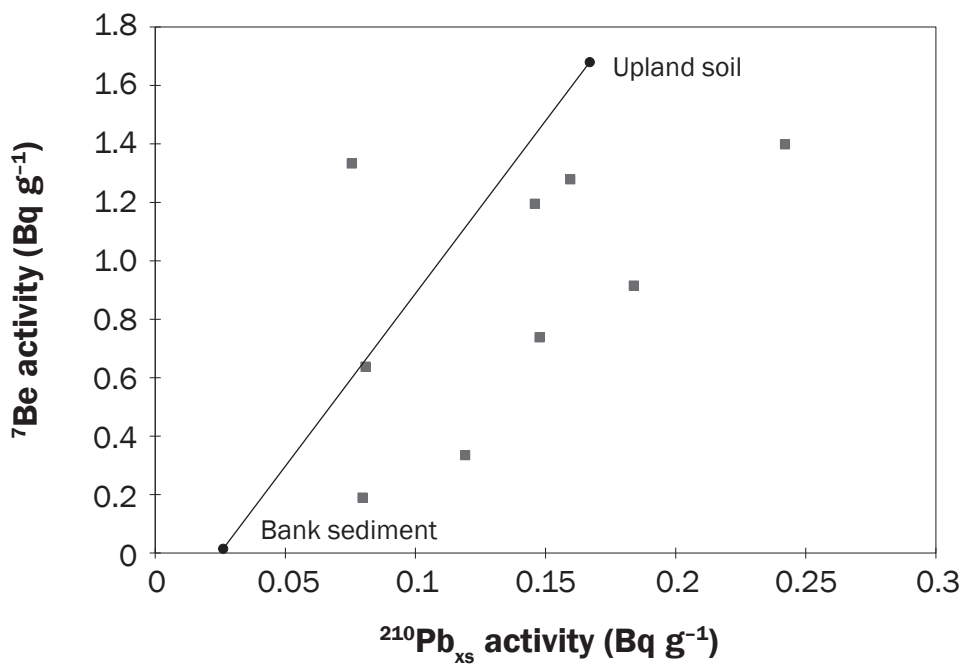

(c)

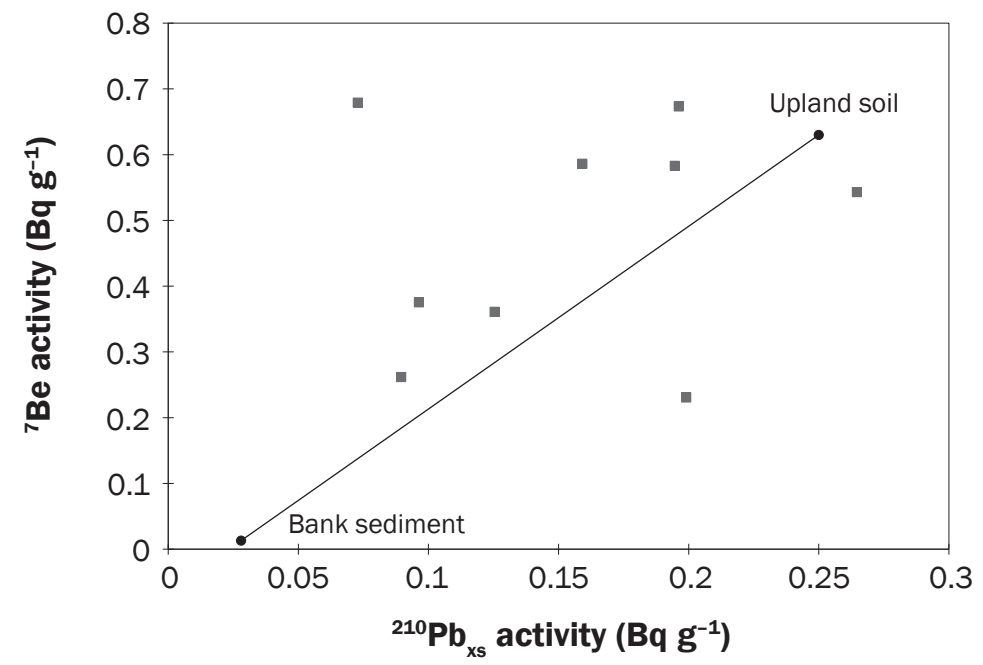

Legend

- Sources - Suspended sediment
The results of these two end-member mixing models for Goodwater Creek and the Cedar Creek subwatershed are provided as examples in figure 5, which shows the streamflow hydrographs at the two sites for the sampled runoff events. Each suspended sediment sample collected during the event is plotted along the hydrograph as a pie chart. The different portions of the pie charts represent the proportions in the fine suspended sediment samples comprised of eroded surface soils and channel bank sources. For the most part, higher proportions of eroded surface soils were present at the beginning stages or rising limb of the hydrograph. This pattern was observed at both Goodwin Creek and the Upper Big Walnut Creek subwatershed, as well as other sites presented in Wilson et al. (2008a).

The higher proportions of eroded upland soils during the beginning of the sampled events were attributed to rapid mobilization by runoff of fine, loose particles deposited during previous runoff events or particles that were loosened by rain splash (Ghadiri et al. 2001). Following this first flush of easily entrained soils by overland flow, the amount of sediment delivered to the stream was significantly reduced as runoff velocities decreased and its ability to transport sediment also decreased (Deletic 1998; Rossi et al. 2005; Stutter et al. 2008). The first flush phenomenon was also seen in Wilson et al. (2012), where between $75 \%$ and $88 \%$ of the total sediment mobilized during the events were measured during the first half the runoff events as based on the cumulative mass of water. As flow and fine suspended sediment concentration increased, the proportions of eroded surface soils decreased substantially corresponding to decreases in activities of ${ }^{7} \mathrm{Be}$ and ${ }^{210} \mathrm{~Pb}_{\mathrm{xs}}$ of the fine suspended sediments (Wilson and Kuhnle 2006). The increase of water in the channel and resulting shear stress would enhance fluvial erosion of the stream banks, whereas, increased soil-water pressures from infiltration decrease the soil's apparent cohesion thereby promoting bank collapse. Rinaldi and Casagli (1999) reported that bank failures typically occur during the recession limb of stream hydrographs.

The overall partitioning of the sampled runoff event in each watershed was determined by applying the relative partitioning of each sample with the associated sediment flux and integrating over the entire event. For Goodwater Creek, which was the largest of the sampled watersheds $\left(72 \mathrm{~km}^{2}\right.$ [44.7 


\section{Figure 5}

Relative partitioning of suspended sediment collected during the sampled runoff events at (a) Goodwater Creek and (b) Cedar Creek. The $x$-axes in these graphs show the event time, which started from the initiation of the rainfall and ended when the discharge returned to baseflow conditions. The $y$-axes are the measured discharge during those sampled events. Each suspended sediment sample collected during the events is plotted along the hydrograph at the time of its collection as a pie chart. The blue portions of the graphs represent the amount of eroded surface soils in the suspended sediment load relative the amount of channel bank sediments, which are represented by the red portions of the graphs.

(a)

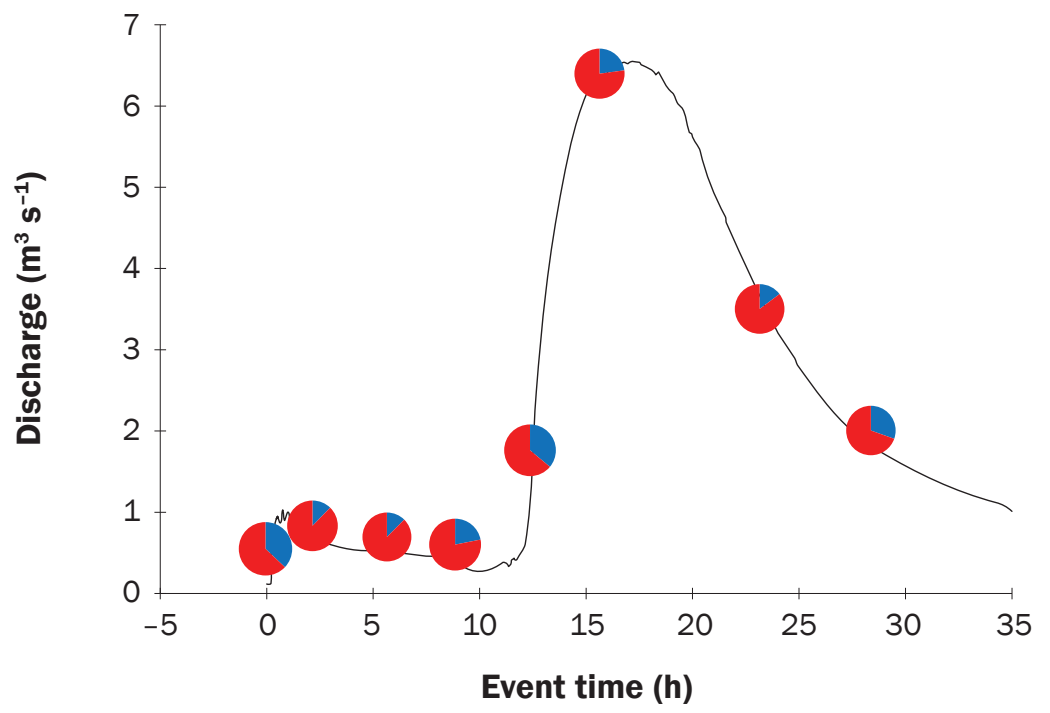

(b)

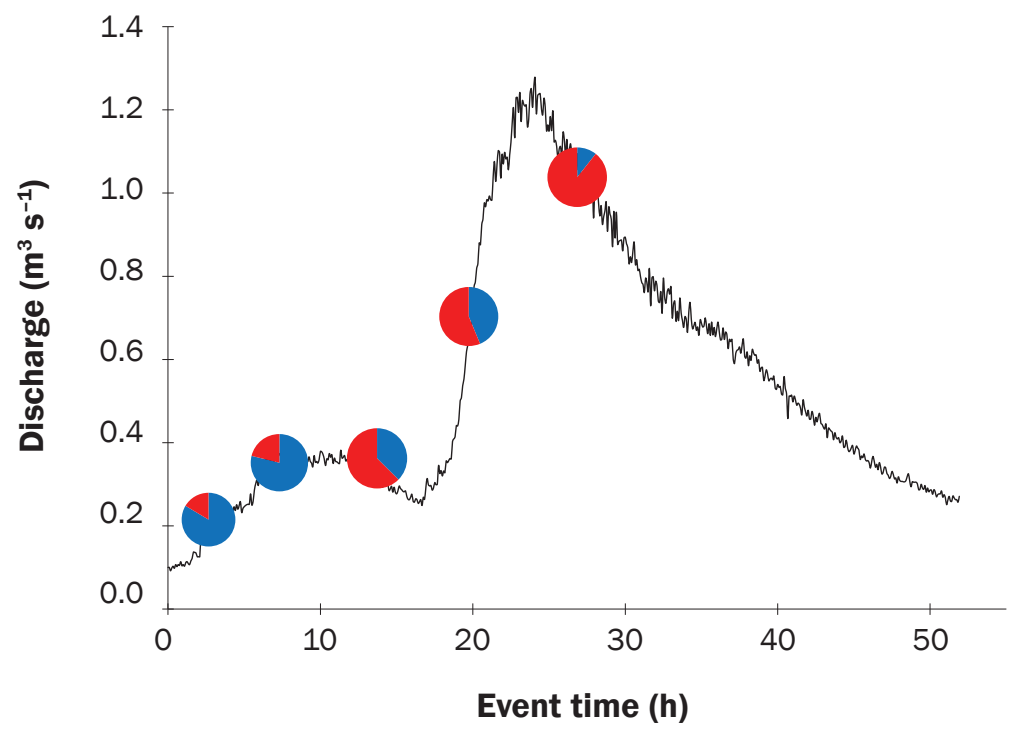

Legend

Upland soil

Bank sediment

$\left.\mathrm{mi}^{2}\right]$ ), the suspended sediment load was comprised of only $25 \%$ eroded surface soils. On the other hand, the suspended sediment load of the Upper Big Walnut Creek sub-watershed $\left(4 \mathrm{~km}^{2}\right.$ [2.5 $\left.\left.\mathrm{mi}^{2}\right]\right)$ was mainly eroded surface material (73\%). Cedar Creek, which had an intermediate size $\left(43 \mathrm{~km}^{2}\right.$ [26.7 $\left.\left.\mathrm{mi}^{2}\right]\right)$, had nearly equal amounts of eroded surface soils and channel bank material in its suspended load. When comparing the integrated percentage of fine sediment derived from channel sources for all eight watersheds of the present study and Wilson et al. (2008), only the subwatersheds of Upper Big Walnut Creek and Cedar Creek had values of channel-derived fine sediment below the 50\% mark (figure 6 and table 3).

The inverse relation between drainage areas and contributions from upland areas was also seen when including the subwatersheds from Wilson et al. 2008a (figure $7)$. If the sampled drainage area was small, the eroded surface soils had less distance to travel and the likelihood of depositing before reaching the stream was decreased relative to larger systems, which incorporated more lowland areas and depressions. Additionally, this is reflected in the relationship between drainage area and the sediment delivery ratio, whereas, in studies such as Abaci and Papanicolaou (2009), the sediment delivery ratio in smaller headwater systems was near unity as most of the eroded sediment reaches the outlet of a system. However, as the drainage area increased, the sediment delivery ratio decreased as the eroded sediment is deposited along the transport path.

It is important to note that these sampled runoff events are only snapshots during a particular season (e.g., growing season) of a single year. More events must be studied to identify the variability of sediment sources between individual events and seasons. The range of variability must be determined before annual average percentages of eroded surface soils and channel contributions to the total load can be quantified. In Goodwin Creek, where four events were sampled in different months of different years, the contributions from the channel ranged between $61 \%$ and $85 \%$, showing that sediment sources can change per event and hence stressing the need for long-term monitoring of sediment source contributions.

Independent Studies. Confirmation of the above results was sought by comparing them to related studies. Three independent studies were identified, where the sources of sediment to the suspended load were determined. Grissinger et al. (1991) calculated that $75 \%$ of the fines load of Goodwin Creek originated from channel sources. Yield values were estimated from gauged subwatersheds within Goodwin Creek, which had single land uses. These values were corrected for slope differences using the Universal Soil Loss Equation length slope topographic factors for the estimation of loads from other areas. The values were summed and com- 


\section{Figure 6}

Percentage of sediment derived from channel sources from the eight watersheds. Cedar Creek, Goodwater Creek, and Upper Big Walnut Creek results are from the current manuscript, while the results from the Fort Cobb Reservoir, South Fork of the lowa River, Little River, and Topashaw Canal are from Wilson et al. (2008a). The results from Godwin Creek are from both the current manuscript and Wilson et al. (2008a).

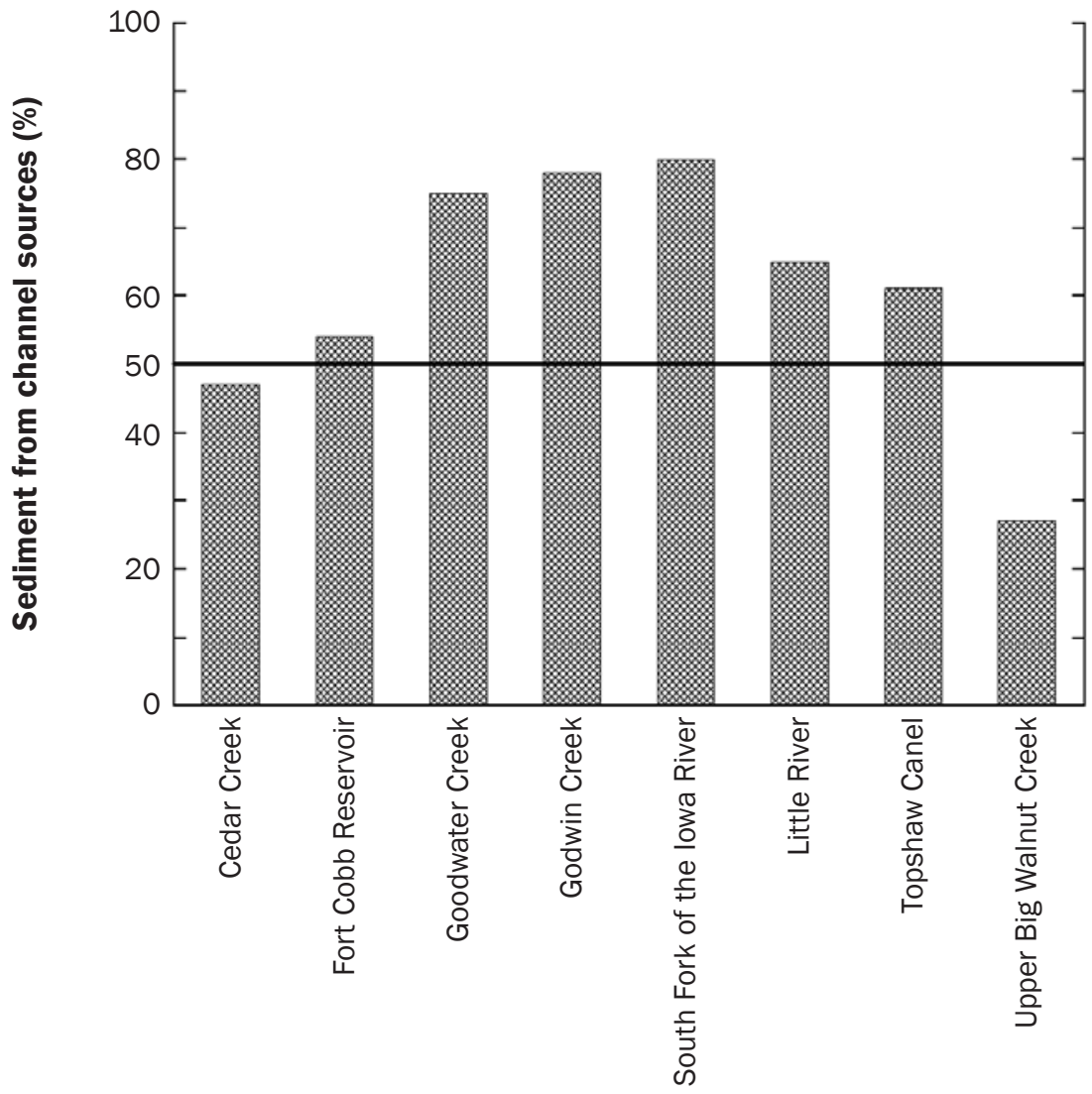

Table 3

Relative partitioning of sediment sources in sampled watersheds.

\begin{tabular}{llll}
\hline Watershed & Date & $\begin{array}{l}\text { Eroded } \\
\text { surface soil- } \\
\text { integrated (\%) }\end{array}$ & $\begin{array}{l}\text { Channel } \\
\text { sediment- } \\
\text { integrated (\%) }\end{array}$ \\
\hline Fort Cobb Reservoir, Oklahoma* & August 15, 2006 & $46 \pm 6$ & $54 \pm 8$ \\
Goodwin Creek, Mississippi† & April 4, 2004 & $15 \pm 5$ & $85 \pm 7$ \\
Goodwin Creek, Mississippi* & January 7, 2005 & $22 \pm 2$ & $78 \pm 5$ \\
Little River, Georgia* & April 8, 2006 & $35 \pm 9$ & $65 \pm 12$ \\
South Fork of lowa River, lowa* & September 10, 2006 & $20 \pm 2$ & $80 \pm 2$ \\
Topashaw Creek, Mississippi* & May 9, 2006 & $39 \pm 4$ & $61 \pm 3$ \\
Goodwin Creek, Mississippi & December 28, 2007 & $39 \pm 4$ & $61 \pm 4$ \\
Goodwin Creek, Mississippi & April 27, 2008 & $24 \pm 2$ & $76 \pm 2$ \\
Upper Big Walnut Creek, Ohio & June 2, 2008 & $73 \pm 14$ & $27 \pm 14$ \\
Cedar Creek, Indiana & July 19, 2007 & $53 \pm 27$ & $47 \pm 27$ \\
Goodwater Creek, Missouri & March 29, 2007 & $25 \pm 10$ & $75 \pm 10$ \\
\hline
\end{tabular}

*Wilson et al. (2008).

†Wilson and Kuhnle (2006).

pared to gauged values from the 14 gauging stations on the watershed. In another study on Goodwin Creek a value of $64 \%$ of the fines was determined as having originated from channel processes (Kuhnle et al. 1996). This value was calculated by comparing the annual fine sediment load calculated from sediment samples and flow data collected from gauging station 1 near the mouth of the watershed to simulated values of fine sediment from upland sources generated using the Soil and Water Assessment Tool model (Green et al. 2006). The channel contributions determined by Grissinger et al. (1991) and Kuhnle et al. (1996) were in the range of bank sediment contributions to Goodwin Creek determined using the method described herein (61\% to 85\%).

Willett et al. (2012) calculated that an average of $88 \%$ of the sediment from two watersheds in the claypan region of Missouri originated from channel sources. The channel bank erosion rates were calculated from quarterly measurements of bank erosion rates from more than 3,000 erosion pins and a survey to determine the fraction of stable and unstable banks in the watersheds. The erosion from upland areas was calculated using data from the USDA National Resources Conservation Service regarding erosion rates from agricultural lands on the two watersheds. The high fraction of sediment originating from channel banks (88\%) in this study was attributed to the fact that discharges in the watersheds were approximately twice the 20-year average for the two years of the study and was close to the values of $75 \%$ from the radionuclide measurements. These studies arrived at the fraction of sediment produced from bank sources using methods independent from the radionuclide method of this study. The fractions of sediment from channel sources for Goodwin Creek and for two watersheds in Missouri were reasonably close to the values determined from the radionuclides ${ }^{7} \mathrm{Be}$ and ${ }^{210} \mathrm{~Pb}_{\mathrm{xs}}$ used on the same and similar watersheds.

It was suggested by Wilson et al. (2008a) that erosion of sediment below a certain depth in gullies during a runoff event may have a similar signature as those originating from channel bank erosion. To shed further light on this, a calculation was made to determine the expected radionuclide signatures from gully erosion over a range of depths (Whiting et al. 2001). The boundary of a hypothetical gully was assumed to 


\section{Figure 7}

Relationship between watershed size and the percentage of sediment derived from upland sources from the eight watersheds.

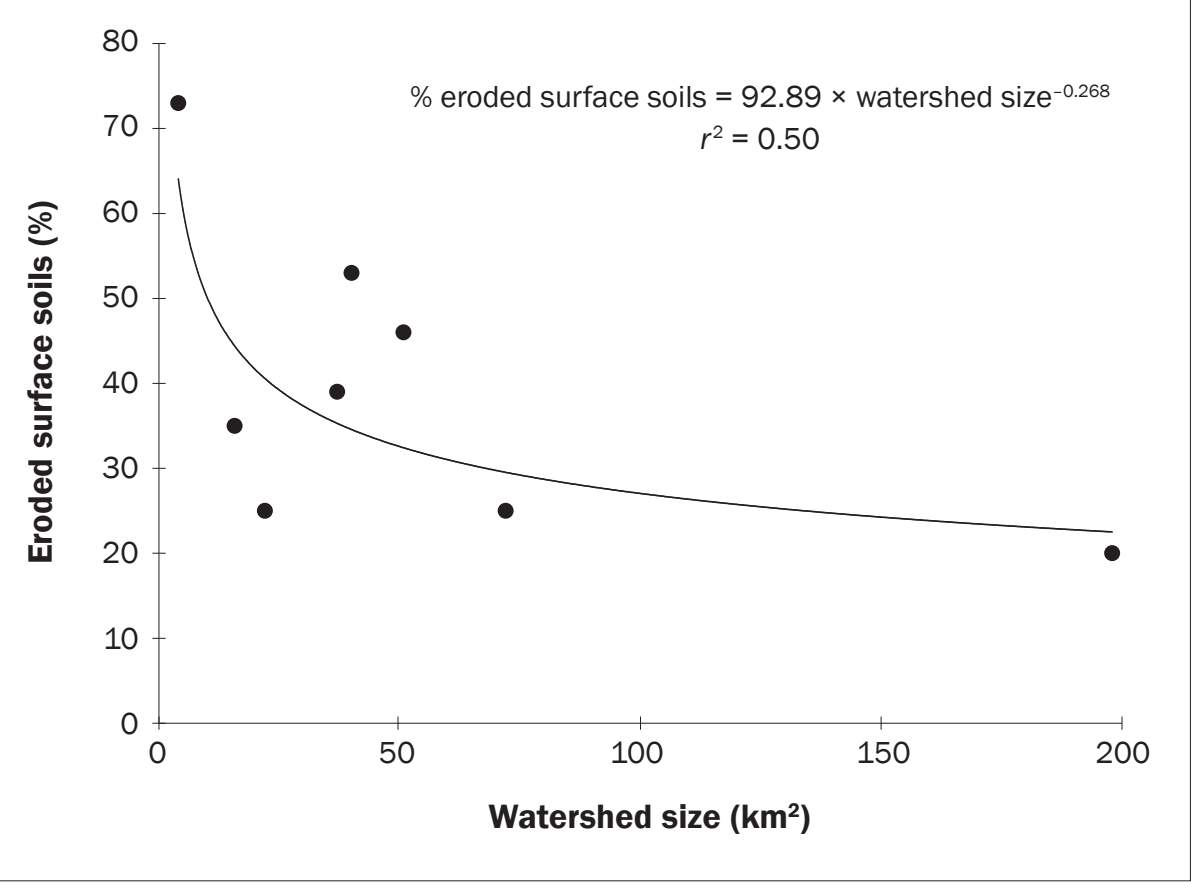

\section{Figure 8}

Apparent percentage of soil from channel processes derived from radionuclide activities for simulated gully erosion versus depth. Distribution of radionuclides assumed to be the same as that measured from potential sediment sources before January 7, 2005, runoff event on Goodwin Creek.

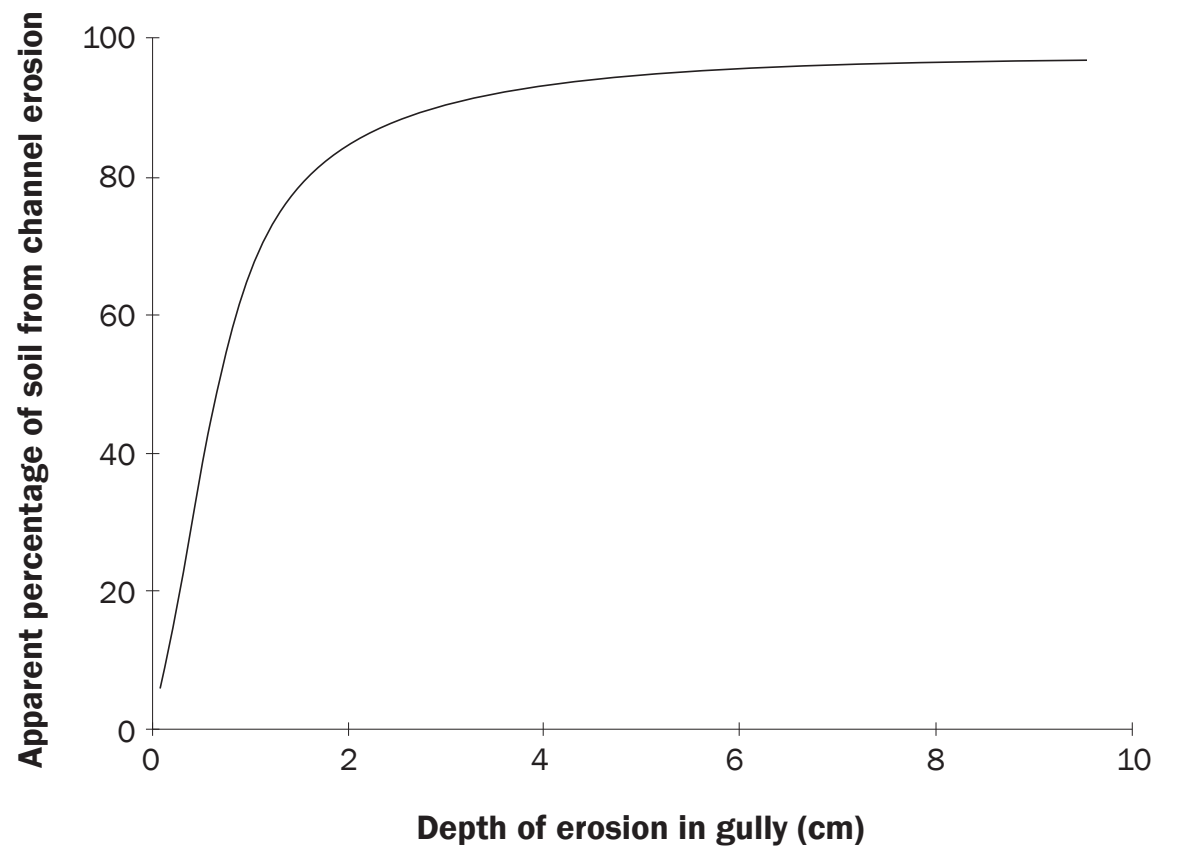


Creek Watershed had a median sediment yield 7.3 times larger, again suggesting important channel contributions. Similarly, the South Fork Watershed was found to have 3.4 times the reference sediment yield of $20 \mathrm{t} \mathrm{y}^{-1} \mathrm{~km}^{-2}$ (57.1 tn $\mathrm{yr}^{-1} \mathrm{mi}^{-2}$ ) for ecoregion 47, the Fort Cobb Watershed 75 times the reference of $19 \mathrm{t} \mathrm{y}^{-1} \mathrm{~km}^{-2}$ (54.2 $\mathrm{tn} \mathrm{yr}^{-1}$ $\mathrm{mi}^{-2}$ ) for ecoregion 27, and Little River Watershed had sediment yield similar to the reference of $8.6 \mathrm{t} \mathrm{y}^{-1} \mathrm{~km}^{-2}$ (24.6 $\mathrm{tn} \mathrm{yr}^{-1} \mathrm{mi}^{-2}$ ) for ecoregion 65 . Thus, while isotopic analysis found that more than $60 \%$ of the Little River sediment yield had a channel signature, channel banks were hard to identify and the absolute sediment yield values were similar to that of reference watersheds with stable streams. These results underscore that upland concentrated flow erosion processes likely contributed to channel sources inferred from isotopic analysis and that the percentage of sediment from channel sources says nothing about the magnitude of sediment yields. Nevertheless, isotopic analysis provides complementary information to more conventional assessment methodologies that enables more complete understating of erosion and sediment transport processes.

\section{Summary and Conclusions}

A method using two naturally occurring radionuclides was used in eight CEAP watersheds to determine the fractions of sediment which originated from upland and channel sources. This method has indicated that in six of the eight watersheds more than $50 \%$ of the suspended sediment in the channels originated from channel sources. Knowledge of the dominant sediment source could help guide the designing and implementation of conservation practices. If the channel boundary is a major source of sediment in an agricultural watershed, conservation practices must be considered which directly target the channel sources of sediment. This study also indicates that determinations of channel-derived sediment arrived at from using two radionuclides may also originate from gully processes if single erosion events are deeper than about $1 \mathrm{~cm}$ (0.39 in). When a watershed is found to have a large fraction of sediment from channel-derived sources, gullies should be considered as a potential part of this channel-derived sediment. This distinction is especially important in watersheds in which there is evidence for gully activity. For the presented methodology, gully sources should be considered as one of the possible channel sources.

\section{References}

Abaci, O., and A.N. Papanicolaou. 2009. Long-term effects of management practices on water-driven soil erosion in an intense agricultural sub-watershed: monitoring and modeling. Hydrological Processes 23:2818-2837.

Arnold, J.R., and H.A. Al-Salih. 1955. Beryllium-7 produced by cosmic rays. Science 121:451-453.

Baskaran, M., C.H. Coleman, and P.H. Santshci. 1993. Atmospheric depositional fluxes of ${ }^{7} \mathrm{Be}$ and ${ }^{210} \mathrm{~Pb}$ at Galveston and College Station, Texas. Journal of Geophysical Research 98(D11):20555-20571.

Bennett, S.J., C.V.Alonso, S.N. Prasad, and M.J.M. Romkens. 2000. Experiments on headcut growth in concentrated flows typical of upland areas. Water Resources Research 36(7):1911-1922.

Bierman, P.R., A. Albrecht, M.H. Bothner, E.T. Brown, T.D. Bullen, L.B. Gray, and L. Turpin. 1998. Erosion, Weathering, and Sedimentation. In Isotope Tracers in Hydrology, eds. C. Kendall, and J.J. McDonnell. Amsterdam, Netherlands: Elsevier Science 19: 647-678.

Bingner, R.L., F.D. Theurer, and D.S. Moore. 2006. Watershed conservation management planning using AGNPS. In Proceedings of the Second Sino-American Workshop on Advanced Computational Modeling in Hydroscience and Engineering, Beijing, China November 25-26, 2006.

Bonniwell, E.C., G. Matisoff, and P.J. Whiting. 1999. Determining the times and distances of particle transit in a mountain stream using fallout radionuclides. Geomorphology 27:75-92.

Bonniwell, E.C. 2001. Evaluating Soil Erosion and Sediment Transport with Radionuclides. PhD Dissertation, Case Western Reserve University.

Brigham, M., C. McCullough, and P. Wilkinson. 2001. Analysis of suspended sediment concentrations and radioisotope levels in the Wild River Basin, Northwest Minnesota, 1973-98. US Geological Survey Water Resources Investigations Report 01-4192.

Cutshall, N.H., I.L.Larsen, and C.R. Olsen. 1983. Direct analysis of ${ }^{210} \mathrm{~Pb}$ in sediment samples: Self-absorption correction. Nuclear Instruments and Methods 206:309-312.

Deletic, A., 1998. The first flush load of urban surface runoff. Water Resources 32:2462-2470.

Dendy, F.E., S.J. Ursic, and A.J. Bowie. 1979. Sediment sources and yields from upland watersheds in north Mississippi. In Proceedings Mississippi Water Resources Conference, Mississippi, 49-54. Water Resource Research Institute

Dibb, J.E., and D.L. Rice. 1989. The geochemistry of Beryllium-7 in Chesapeake Bay. Estuarine, Coastal, and Shelf Science 28:379-394.

Duffy, M. 2012. Value of soil erosion to the land owner. Iowa State University Extension Ag Decision Maker. Publication A1-75. Ames, IA: Iowa State University Extension.
Duriancik, L.F., D. Bucks, J.P. Dobrowolski, T. Drewes, S.D. Eckles, L. Jolley, R.L. Kellog, D. Lund, J.R. Makuch, M.P. O’Neill, C.A. Rewa, M.R. Walbridge, R. Parry, and M.A. Weltz. 2008. The first five years of the Conservation Effects Assessment Project. Journal of Soil and Water Conservation 63(6):185A-197A, doi:10.2489/jswc.63.6.185A.

Ghadiri, H., C.W. Rose, and H.L. Hogarth. 2001. The influence of grass and porous barrier strips on runoff hydrology and sediment transport. Transactions of the American Society of Agricultural Engineers 44:259-268.

Grissinger, E.H., A.J. Bowie, and J.B. Murphey. 1991. Goodwin Creek bank instability and sediment yield. 5th Federal Interagency Sedimentation Conference, Las Vegas, Nevada, v.2, PS-32-PS-39.

Green, C.H., M.D. Tomer, M. DiLuzio, and J. Arnold. 2006. Hydrologic calibration of the Soil and Water Assessment Tool for a large tile-drained watershed in Iowa. Transactions American Society of American Biological Engineers 49:413-422.

Hawley, N., J.A. Robbins, and B.J. Eadie. 1986. The partitioning of ${ }^{7}$ Beryllium in fresh water. Geochimica et Cosmochimica Acta 50:1127-1131.

He, Q., and D.E. Walling. 1996. Interpreting particle size effects in the adsorption of ${ }^{137} \mathrm{Cs}$ and Unsupported ${ }^{210} \mathrm{~Pb}$ by mineral soils and sediment. Journal of Environmental Radioactivity 30(2):117-137.

He, Q., and D.E. Walling. 1997. The distribution of fallout ${ }^{137} \mathrm{Cs}$ and ${ }^{210} \mathrm{~Pb}$ in undisturbed and cultivated soils. Applied Radiation and Isotopes 48(5):677-690.

Helmers, M., T. Isenhart, C. Kling, T. Moorman, W. Simpkins, and M. Tomer. 2007. Agriculture and water quality in the Cornbelt: Overview of issues and approaches. Choices 22:79-85.

Kuhnle, R.A., R.L. Bingner, C.V. Alonso, C.G. Wilson, and A. Simon. 2008. Conservation practice effects on sediment load in the Goodwin Creek Experimental Watershed. Journal of Soil and Water Conservation 63(6):496-503, doi:10.2489/jswc.63.6.496.

Kuhnle, R.A., R.L. Bingner, G.R. Foster, and E.H. Grissinger. 1996. Effect of land use changes on sediment transport in Goodwin Creek. Water Resources Research 32(10):3189-3196.

McGregor, K.C., J.D. Greer, G.E. Gurley, and G.C. Bolton. 1969. Runoff and sediment production from north Mississippi loessial soils. State College, MS: Agricultural Experiment Station, Mississippi State University Bulletin 777.

Matisoff, G., E.C. Bonniwell, and P.J. Whiting. 2002a. Soil erosion and sediment sources in an Ohio watershed using Beryllium-7, Cesium-137, and Lead-210. Journal of Environmental Quality 31(1):54-61.

Matisoff, G., E.C. Bonniwell, and P.J. Whiting. 2002b. Radionuclides as indicators of sediment transport in agricultural watersheds that drain to Lake Erie. Journal of Environmental Quality 31(1):62-72. 
Matisoff, G., C.G. Wilson, and P.J. Whiting. 2005. ${ }^{7} \mathrm{Be} /{ }^{210} \mathrm{~Pb}$ ratio as an indicator of suspended sediment age or fraction new sediment in suspension. Earth Surface Processes and Landforms 30(9):1191-1201.

Newcombe, C.P., and J.O.T. Jensen. 1996. Channel suspended sediment and fisheries: a synthesis for quantitative assessment of risk and impact. North American Journal of Fisheries and Management 16(4):693-727.

Newcombe, C.P., and D.D. MacDonald. 1991. Effects of suspended sediments on aquatic ecosystems. North American Journal of Fisheries and Management 11:72-82.

Osterkamp, W.R., P. Heilman, and L.J. Lane. 1998 Economic considerations of a continental sedimentmonitoring program. International Journal of Sediment Research 13(4):12-24.

Owens, P.N., D.E. Walling, and Q. He. 1996. The behavior of bomb-derived cesium-137 fallout in catchment soils. Journal of Environmental Radioactivity 32(3):169-191.

Peart, M.R., and D.E. Walling. 1986. Fingerprinting in sediment sources: The example of a drainage basin in Devon, UK. In Drainage Basin Sediment Delivery. International Association of Hydrological Sciences Publication 159:41-55.

Rabalais, N.N., R.E. Turner, W.J. Wiseman, Jr., and D.F. Boesch. 1991. A brief summary of hypoxia on the northern Gulf of Mexico continental shelf: 1985-1988. In Modern and Ancient Continental Shelf Anoxia, eds. R.V. Tyson, T.H. Pearson. Geological Society Special Publication 58.

Rhoton, F.E., W.E. Emmerich, D.A. DiCarlo, D.S. McChesney, M.A. Nearing, and J.C. Ritchie, 2008. Identification of suspended sources using soil characteristics in a semiarid watershed. Soil Science Society of America Journal 72(4):1102-1112.

Rhoton, F.E., N.E. Smeck, and L.P. Wilding. 1979. Preferential clay mineral erosion from watersheds in the Maumee River Basin. Journal of Environmental Quality 8(4):547-550.

Robbins, J.A., and B.J. Eadie. 1991. Seasonal cycling of trace elements ${ }^{137} \mathrm{Cs},{ }^{7} \mathrm{Be}$, and ${ }^{239+240} \mathrm{Pu}$ in Lake Michigan. Journal of Geophysical Research 96(C9):17081-17104.

Roehl J.E., 1962. Sediment source areas and delivery ratios influencing morphological factors. International Association of Hydrological Sciences 59:202-213.

Rossi, L., V. Krejci, W. Rauch, S. Kreikenbaum, R. Frankhauser, and W. Gujer. 2005 Stochastic modeling of total suspended solids (TSS) in urban areas during rain events. Water Resources 39:4188-4196.

Rinaldi, M., and N. Casagli. 1999. Stability of streambanks formed in partially saturated soils and effects of negative pore water pressures: The Sieve River (Italy). Geomorphology 26:253-277.

Rutledge,E.M.,L.P.Wilding, and M.Elfield.1967.Automated particle size separation by sedimentation. Soil Science Society of America Proceedings 31:297-288.
Schilling, K., M. Tomer, P. Gassman, C. Kling, T. Isenhart, T. Moorman, W. Simpkins, and C. Wolter. 2007. A tale of three watersheds: Nonpoint source pollution and conservation practices in Iowa. Choices 22:87-95.

Shields, F.D., Jr., S.S. Knight, and C.M. Cooper. 1994 Effects of channel incision on base flow stream habitats and fishes. Environmental Management 18(1):43-57.

Simon, A., and L. Klimetz. 2008. Relative magnitudes and sources of sediment in benchmark watersheds of the Conservation Effects Assessment Project. Journal of Soil and Water Conservation 63(6):504-522, doi:10.2489/ jswc.63.6.504.

Smith, G.F., K.N. Greenhawk, D.G. Bruce, E.B. Roach, and S.J. Jordan. 2001. A digital presentation of the Maryland oyster habitat and associated bottom types in the Chesapeake Bay (1974-1983). Journal of Shellfish Research 20:192-206.

Stutter, M.I., S.J. Langan, and R.J. Cooper. 2008. Spatial contributions of diffuse inputs and within-channel processes to the form of stream water phosphorus over storm events. Journal of Hydrology 350:203-214.

Todd, J.F., G.T.F. Wong, and C.R. Olsen. 1989 Atmospheric depositional characteristics of beryllium 7 and lead 210 along the southeastern Virginia coast. Journal of Geophysical Research 94(D8):11106-11116.

Turekian, K.K., L.K. Benninger, and E.P. Dion. 1983 ${ }^{7} \mathrm{Be}$ and ${ }^{210} \mathrm{~Pb}$ total deposition fluxes at New Haven, Connecticut and at Bermuda. Journal of Geophysical Research 88(C9):5411-5415.

Van Oost, K., G. Govers, S. de Alba, and T. Quine. 2006. Tillage erosion: Review of controlling factors and implications for soil quality. Progress in Physical Geography 30:443-466.

Wallbrink, P.J., and A.S. Murray. 1996. Distribution and variability of ${ }^{7} \mathrm{Be}$ in soils under different cover conditions and its potential for describing soil redistribution processes. Water Resources Research 32(2):467-476.

Walling, D.E., and J.C. Woodward. 1992. Use of radiometric fingerprints to derive information on suspended sediment sources. In Erosion and Sediment Transport Monitoring Programs in River Basins. International Association of Hydrological Sciences Publication 210:153-164.

Wells, R.R., C.V. Alonso, and S.J. Bennett. 2009 Morphodynamics of headcut development and soil erosion in upland concentrated flows. Soil Science Society of America Journal 73(2):521-530.

Wells, R.R., H.G. Momm, J.R. Rigby, S.J. Bennett, R.L. Bingner, and S.M. Dabney. 2013. An empirical investigation of gully widening rates in upland concentrated flows. Catena 101:114-121.

Whiting, P.J., E.C. Bonniwell, and G. Matisoff. 2001. Depth and areal extent of sheet and rill erosion based on radionuclides in soils and suspended sediment. Geology 29:1131-1134

Whiting, P.J., G. Matisoff, W.F. Fornes, and F.M. Soster 2005. Suspended sediment sources and transport distances in the Yellowstone basin. GSA Bulletin 117:515-529.

Willett, C.D., R.N. Lerch, R.C. Schultz, S.A. Berges, R.D. Peacher, and T.M. Isenhart. 2012. Streambank erosion in two watersheds of the Central Claypan Region of Missouri, United States. Journal of Soil and Water Conservation 67(4):249-263, doi:10.2489/ jswc.67.4.249

Wilson, C.G. 2003. The Transport of Fine Sediment through Three NERR Estuaries Using Radionuclide Tracers. PhD dissertation, Case Western Reserve University.

Wilson, C.G., G. Matisoff, and P.J.Whiting. 2003. Short-term erosion rates from a ${ }^{7} \mathrm{Be}$ inventory balance. Earth Surface Processes and Landforms 28(9):967-977.

Wilson, C.G., R.A. Kuhnle, D.D. Bosch, J.L. Steiner P.J. Starks, M.D. Tomer, and G.V. Wilson. 2008a. Quantifying relative contributions from sediment sources in Conservation Effects Assessment Project watersheds. Journal of Soil and Water Conservation 63(6):523-532, doi:10.2489/jswc.63.6.523.

Wilson, C.G., and R.A. Kuhnle. 2006. Determining relative contributions of eroded landscape sediment to the suspended load of Goodwin Creek using ${ }^{7} \mathrm{Be}$ and ${ }^{210} \mathrm{~Pb}$ Oxford, MS: USDA ARS National Sedimentation Laboratory Research Report 053.

Wilson, C.G., G. Matisoff, P.J. Whiting, and D.M. Klarer. 2005. Transport of fine sediment through a wetland using radionuclide tracers: Old Woman Creek, $\mathrm{OH}$ Journal of Great Lakers Research 31(1):56-67.

Wilson, C.G., A.N. Papanicolaou, and K.D. Denn. 2012. Partitioning fine sediment loads in an intensively agricultural headwater system. Journal of Soil and Sediments 12:966-981.

Wilson, G.V., F.D. Shields, Jr., R.L. Bingner, P. ReidRhoades, D.A. DiCarlo, and S.M. Dabney. 2008b. Conservation practices and gully erosion contributions in the Topashaw Canal watershed. Journal of Soil and Water Conservation 63(6):420-429, doi:10.2489/ jswc.63.6.420. 